\title{
Pengaruh Zakat Perbankan dan Corporate Social Responsibility terhadap Rasio Profitabilitas Bank Umum Syariah
}

\author{
Indah Nur Ainun', Nofinawati², Windari3 \\ 1,2,Institut Agama Islam Negeri Padangsidimpuan \\ JL. H.T. Rizal Nurdin Km 4,5 Sihitang Kota Padangsidimpuan Sumatera Utara \\ Email: indahnurainun@gmail.com ${ }^{1}$, nofinawati@iain-padangsidimpuan.ac.id ${ }^{2}$, \\ windari@iain-padangsidimpuan.ac.id³
}

\begin{abstract}
Based on data obtained from Islamic Commercial Banks in Indonesia as many as 9 banks the percentage of Banking Zakat, Corporate Social Responsibility and Return On Assets fluctuated, but the increase that occurred in Banking Zakat and Corporate Social Responsibility was not always followed by an increase in Return On Assets. This study aims to determine the effect of banking zakat and corporate social responsibility on the profitability ratios of Islamic Commercial Banks in Indonesia 2013-2018 either partially or simultaneously. This research is a quantitative research, the data source comes from secondary data in the form of pooled data. The results showed that partially banking zakat had a significant effect on return on assets of Islamic Commercial Banks in Indonesia, partially corporate social responsibility had no significant effect on return on assets of Islamic Commercial Banks in Indonesia. Meanwhile, simultaneously banking zakat and corporate social responsibility have a significant influence on the return on assets of Islamic Commercial Banks in Indonesia.
\end{abstract}

Keywords : Banking Zakat, Corporate Social Responsibility, Return On Asset

\begin{abstract}
ABSTRAK
Berdasarkan data yang diperoleh dari Bank Umum Syariah di Indonesia sebanyak 9 bank persentase Zakat Perbankan, Corporate Social Responsibility dan Return On Asset mengalami fluktuasi, namun kenaikan yang terjadi pada Zakat Perbankan dan Corporate Social Responsibility tidak selalu diikuti dengan kenaikan Return On Asset. Penelitian ini bertujuan untuk mengetahui pengaruh zakat perbankan dan corporate social responsibility terhadap rasio profitabilitas Bank Umum Syariah di Indonesia 2013-2018 baik secara parsial maupun secara simultan. Penelitian ini adalah penelitian kuantitatif, sumber data berasal dari data sekunder dengan bentuk pooled data. Hasil penelitian menunjukkan secara parsial zakat perbankan berpengaruh signifikan terhadap return on asset Bank Umum Syariah di Indonesia, corporate social responsibility secara parsial tidak berpengaruh signifikan terhadap return on asset Bank Umum Syariah di Indonesia. Sedangkan secara simultan zakat perbankan dan corporate social responsibility memiliki pengaruh yang signifikan terhadap return on asset Bank Umum Syariah di Indonesia.
\end{abstract}

Kata Kunci : Zakat Perbankan, Corporate Social Responsibility, Return On Asset 


\section{PENDAHULUAN}

Bank adalah suatu badan usaha yang menghimpun dana dari masyarakat dalam bentuk simpanan dan menyalurkannya kembali kepada masyarakat dalam bentuk kredit atau bentuk lainnya dalam rangka meningkatkan taraf hidup rakyat. Hal ini sesuai dengan UndangUndang Perbankan No. 21 tahun 2008 tentang perbankan syariah (Anggota Ikapi, 2008:39). Kinerja keuangan bank akan menunjukkan kemampuan suatu perusahaan dalam mengelola dan mengalokasikan sumber dayanya. Penilaian kinerja bank dilakukan dengan menganalisa dan mengevaluasi laporan keuangan. Rasio merupakan alat ukur yang digunakan untuk menganalisis laporan keuangan. Rasio menggambarkan suatu hubungan atau pertimbangan antara suatu jumlah tertentu dengan jumlah yang lain. Dengan menggunakan analisis berupa rasio keuangan dapat menjelaskan dan memberikan gambaran baik buruknya kinerja suatu bank dari suatu periode ke periode berikutnya. Salah satu rasio keuangan yang digunakan untuk melihat kemampuan bank dalam mengelola dana adalah rasio profitabilias yang diukur dengan return on asset.

Return on asset lebih memfokuskan pada kemampuan perusahaan untuk memperoleh earning dalam operasi perusahaan secara keseluruhan. Selain itu dalam penentuan tingkat kesehatan suatu bank, Bank Indonesia lebih mementingkan penilaian return on asset dari pada return on equity karena Bank Indonesia lebih mengutamakan nilai profitabilitas suatu bank yang diukur dengan asetnya yang dananya sebagian besar berasal dari dana simpanan masyarakat (Ardhi Abdillah, 2015:4). Dalam perkembangannya return on asset pada bank umum syariah Indonesia mengalami fluktuasi dari tahun 2013-2018. Seperti yang terlihat dari tabel 1 dibawah ini:

Tabel 1

\section{Return on asset Pada Bank Umum Syariah}

\begin{tabular}{|l|c|c|c|c|c|c|}
\hline \multirow{2}{*}{$\begin{array}{c}\text { Nama } \\
\text { Bank }\end{array}$} & \multicolumn{7}{|c|}{ Tahun } \\
\cline { 2 - 7 } & $\mathbf{2 0 1 3}$ & $\mathbf{2 0 1 4}$ & $\mathbf{2 0 1 5}$ & $\mathbf{2 0 1 6}$ & $\mathbf{2 0 1 7}$ & $\mathbf{2 0 1 8}$ \\
\hline PT. BMI & $0,50 \%$ & $0,17 \%$ & $0,20 \%$ & $0,22 \%$ & $0,11 \%$ & $0,08 \%$ \\
\hline PT. BNIS & $1,37 \%$ & $1,27 \%$ & $1,43 \%$ & $1,44 \%$ & $1,31 \%$ & $1,42 \%$ \\
\hline PT. BRIS & $1,15 \%$ & $0,08 \%$ & $0,77 \%$ & $0,95 \%$ & $0,51 \%$ & $0,43 \%$ \\
\hline PT. BMS & $1,14 \%$ & $1,16 \%$ & $1,97 \%$ & $2,63 \%$ & $1,56 \%$ & $0,93 \%$ \\
\hline PT. MBS & $2,87 \%$ & $3,61 \%$ & $2,13 \%$ & $9,51 \%$ & $5,5 \%$ & $6,68 \%$ \\
\hline PT. BPS & $1,03 \%$ & $1,99 \%$ & $1,14 \%$ & $0,37 \%$ & $-10,77 \%$ & $0,26 \%$ \\
\hline PT. BCAS & $0,1 \%$ & $0,8 \%$ & $1,0 \%$ & $1,1 \%$ & $1,2 \%$ & $1,2 \%$ \\
\hline PT. BAS & $3,44 \%$ & $3,22 \%$ & $2,83 \%$ & $2,48 \%$ & $2,51 \%$ & $2,38 \%$ \\
\hline PT. BBS & $0,69 \%$ & $0,27 \%$ & $0,79 \%$ & $1,12 \%$ & $0,02 \%$ & $0,02 \%$ \\
\hline
\end{tabular}

JISFIM: Journal of Islamic Social Finance Management, Volume 2, No 2 Tahun 2021 http://jurnal.iain-padangsidimpuan.ac.id/index.php/JISFIM 
Sumber: Publikasi annual report masing-masing bank umum syariah (data diolah, 2020)

Berdasarkan tabel di atas dapat dilihat bahwa secara garis besar return on asset pada bank umum syariah menurun. Penurunan yang signifikan terjadi pada PT. Bank Panin Syariah yaitu pada tahun 2017 mengalami penurunan sebesar 10,40\% dari tahun sebelumnya.

Selain kinerja keuangan bank umum syariah terdapat hal yang harus diperhatikan yaitu kinerja sosial bank umum syariah. Salah satu kinerja sosial yang dilakukan oleh bank umum syariah adalah program tanggung jawab sosial perusahaan atau corporate social responsibility (CSR). Terbukti dengan adanya kewajiban bank syariah dalam mempublikasikan laporan sumber penggunaan dana zakat dan corporate social responsibility.

Zakat merupakan bagian dari konsep Corporate Social Responsibility (CSR) yang akan memberikan panduan pada perusahaan untuk memperhatikan kepentingan sosial disamping kepentingan perusahaan itu sendiri. Kedermawanan perusahaan diwadahi dan dilambangkan sebagai zakat pengusaha maupun perusahaan. Zakat merupakan suatu kewajiban bagi umat muslim yang tergolong mampu (Didin Hafidhuddin, 2007:214). Landasan hukum kewajiban zakat perusahaan terdapat dalam Undang-Undang No. 23 Tahun 2011, tentang Pengelolaan Zakat, Bab IV pasal 11 ayat (2) bagian (b) dikemukaan bahwa diantara objek zakat yang wajib dikeluarkan zakat-nya adalah perdagangan dan perusahaan (Didin Hafidhuddin, 2002:101).

Bank syariah atau perusahaan tidak hanya mengeluarkan dana zakat tetapi bank syariah atau perusahaan juga memiliki tanggung jawab sosial yang harus dipenuhinya sesuai dengan Pasal 74 ayat (1) Undang-Undang Perseroan Terbatas (Hendrik Budi Untung, 2009:15).

Pada awal perkembangannya, program corporate social responsibility (CSR) yang paling umum dilaksanakan oleh perusahaan-perusahaan adalah pemberian bantuan sosial terhadap masyarakat yang hidup di sekitar perusahaan. Pendekatan corporate social responsibility yang berdasarkan pada sosial dan kemanusiaan ini pada umumnya dilakukan hanya untuk mempertahankan citra positif perusahaan dimata masyarakat. Pembentukan citra perusahaan yang ramah lingkungan dan peduli terhadap masyarakat yang tinggal disekitar tempat usaha akan membuat pengoperasian bisnis berjalan lancar. Cepat atau lambat, perusahaan tersebut akan menuai hasilnya yaitu peningkatan keuntungan bank syariah.

Citra positif perusahaan yang terbentuk tidak dapat direkayasa, karena citra akan datang dengan sendirinya dari upaya yang dilaksanakan oleh perusahaan, sehingga komunikasi dan keterbukaan perusahaan merupakan salah satu faktor utama untuk mendapat citra perusahan yang positif. Salah satu keuntungan apabila perusahaan menerapkan 
corporate sosial responsibility secara berkelanjutan meningkatkan dan menguatkan profitabilitas suatu perusahaan (Cindy Widyastuti, 2017:7).

\section{METODE PENELITIAN}

\section{Lokasi dan Waktu Penelitian}

Penelitian ini dilakukan pada Bank Umum Syariah di Indonesia. Waktu penelitian dilaksanakan dari bulan Agustus 2019 sampai dengan selesai. Melalui situs resmi BI www.bi.go.id dan OJK www.ojk.go.id.

\section{Jenis Penelitian}

Jenis penelitian yang digunakan dalam penelitian ini adalah penelitian kuantitatif. Penelitian ini merupakan penelitian kuantitatif dalam bentuk data rasio dan berdasarkan pada runtun waktu (time series) yaitu data yang secara kronologis disusun menurut pengaruh perubahan dalam rentang waktu. Data tersebut diperoleh dari laporan keuangan Bank Umum Syariah yang dipublikasikan.

\section{Sumber Data}

Adapun sumber data dalam penelitian ini adalah data sekunder. Dimana data sekunder adalah data yang telah dikumpulkan oleh pihak lain yang biasanya dikumpulkan oleh lembaga pengumpul data dan dipublikasikan melalui website $w w w . b i . g o . i d$ dan $w w w . o j k . g o . i d$ kepada masyarakat pengguna data (Mudrajat Kuncoro, 2009:148). Dalam penelitian ini digunakan data sekunder dari laporan keuangan publikasi tahunan pada Bank Umum Syariah di Indonesia.

\section{Populasi dan Sampel}

Populasi adalah objek atau subjek yang mempunyai kualitas dan karakteristik tertentu yang diterapkan oleh peneliti untuk dipelajari dan kemudian ditarik kesimpulannya (Sugiyono, 2016:80). Adapun populasi dalam penelitian ini adalah laporan tahunan zakat perbankan, corporate social responsibility dan laporan tahunan rasio profitabilitas pada Bank Umum Syariah di Indonesia dari tahun 2013-2018 yang telah dipublikasikan oleh tiap-tiap Bank Umum Syariah. Penelitian ini dilakukan dalam kurun waktu 2013-2018 = 6 tahun dengan laporan zakat perbankan, corporate social responsibility dan rasio profitabilitas dan dengan Bank Umum Syariah yang berjumlah 14. Maka populasi pada penelitian ini $6 \times 14=84$. 
Menurut Ahmad Nizar sampel adalah sebagian dari objek yang akan diteliti yang dipilih sedemikian rupa sehingga mewakili keseluruhan objek (populasi) yang ingin diteliti (Ahmad Nizar, 2016:46). Sampel yang digunakan adalah bagian dari jumlah dan karakteristik yang dimiliki oleh populasi tersebut. Teknik pengambilan sampel dilakukan secara purposive sampling. Purposive sampling adalah teknik pengambilan sampel dengan peritimbangan atau kriteria tertentu.

Jumlah bank umum syariah di indonesia saat ini sebanyak 14 bank, berdasarkan kriteria yang ditetapkan ada 9 bank yang memenuhi kriteria. Maka sampel dalam penelitian ini berjumlah 9 x 6 totalnya 54 sampel.

\section{Teknik Pengumpulan Data}

Metode pengumpulan data adalah bagian instrumen pengumpulan data yang menentukan berhasil atau tidaknya suatu penelitian (Burhan Bungin, 2001:123). Adapun data yang digunakan adalah data sekunder dan menjadi sumber penelitian yaitu berasal dari situs Bank Indonesia, Otoritas Jasa Keuangan dan Annual Report, jurnal-jurnal, buku-buku maupun sumber-sumber lainnya yang berkaitan dengan penelitian ini.

\section{Teknik Analisis Data}

Teknik analisis data yang digunakan dalam penelitian ini terdiri atas analisis deskriptif, pemilihan model data panel, uji normalitas, analisis regresi linier berganda, uji parsial (uji t), uji statistik f (uji f) dan koefisien determinasi.

\section{HASIL DAN PEMBAHASAN}

\section{Kinerja Keuangan}

Kinerja keuangan secara keseluruhan merupakan gambaran prestasi yang dicapai bank dalam operasionalnya baik menyangkut aspek keuangan, pemasaran, penghimpunan dan penyaluran dana, teknologi maupun sumber daya manusia (Irham Fahmi, 2015:24).

Kinerja keuangan adalah suatu analisis yang dilakukan untuk melihat sejauh mana suatu perusahaan telah melaksanakan dengan menggunakan aturan-aturan pelaksanaan keuangan secara baik dan benar(Jumingan, 2011:239).

Dalam UU RI No. 7 Tahun 1992 tentang perbankan disebutkan bahwa Bank Indonesia berhak untuk menetapkan ketentuan tentang kesehatan bank dengan memperhatikan aspek permodalan, kualitas aset, rentabilitas, likuiditas, solvabilitas dan aspek lainnya yang berkaian dengan usaha bank (Nizamulloh, 2014).

JISFIM: Journal of Islamic Social Finance Management, Volume 2, No 2 Tahun 2021 http://jurnal.iain-padangsidimpuan.ac.id/index.php/JISFIM 


\section{Pengukuran Kinerja Keuangan}

Pengukuran kinerja keuangan dilakukan bersamaan dengan proses analisis. Analisis kinerja keuangan merupakan suatu proses pengkajian kinerja secara kritis, yang meliputi peninjauan data keuangan, perhitungan, pengukuran, interprestasi dan pemberi solusi terhadap masalah keuangan perusahaan pada periode tertentu (Hery, 2015:29).

Tujuan penilaian kinerja keuangan yaitu; untuk mengetahui keberhasilan pengelolaan keuangan perusahaan terutama kondisi likuiditas, kecukupan modal dan profitabilitas yang dicapai dalam tahun berjalan maupun tahun sebelumnya; untuk mengetahui kemampuan perusahaan dalam mendayagunakan semua aset yang dimiliki dalam menghasilkan profit secara efisien (Jumingan, 2011:239).

\section{Rasio Keuangan}

Rasio keuangan adalah angka yang diperoleh dari hasil perbandingan satu pos laporan keuangan dengan pos lainnya yang mempunyai hubungan yang relevan dan signifikan. Perbandingan dapat dilakukan antara satu pos dengan pos lainnya dalam satu laporan keuangan atau antar pos yang ada diantara laporan keuangan. Rasio keuangan adalah suatu kajian yang melihat perbandingan antara jumlah-jumlah yang terdapat pada laporan keuang dan dengan menggunakan formula-formula yang dianggap representatif untuk diterapkan (Hery, 2015:161).

\section{Rasio Rentabilitas}

Rasio rentabilitas merupakan rasio yang digunakan untuk mengukur tingkat efisiensi usaha dan profitabilitas yang dicapai oleh bank yang bersangkutan. Rasio rentabilitas dikenal juga sebagai rasio profitabilitas (Kamis, 2008:327).

Salah satu rasio rentabilitas yang digunakan untuk mengukur kemampuan perusahaan dalam menghasilkan laba adalah return on asset. Return on asset (ROA) adalah rasio yang digunakan untuk mengukur manajemen bank dalam memperoleh keuntungan (laba) secara keseluruhan. Semakin besar return on asset suatu bank, maka semakin besar pula tingkat keuntungan yang dicapai bank tersebut dan semakin baik pula posisi bank tersebut dari segi penggunaan asset (Cindy Widyastuti, 2017:17).

JISFIM: Journal of Islamic Social Finance Management, Volume 2, No 2 Tahun 2021 http://jurnal.iain-padangsidimpuan.ac.id/index.php/JISFIM 
Rasio Return On Asset dirumuskan sebagai berikut:

$\mathrm{ROA}=\frac{\text { laba setelah pajak }}{\text { total aset }} \mathrm{X} 100 \%$

\section{Zakat Perbankan}

Zakat merupakan suatu kewajiban yang harus ditunaikan orang Islam apabila sifatsifat dan syarat-syaratnya sudah terpenuhi (Damri Batubara, 2020:138). Zakat merupakan ibadah maliyah yang mempunyai dimensi dan fungsi sosial ekonomi atau pemerataan karunia Allah dan juga merupakan solidaritas sosial, pernyataan rasa kemanusiaan dan keadilan, pembuktian persaudaraan Islam, sebagai pengikat bantin antara golongan kaya dengan miskin dan sebagai penghilang jurang yang menjadi pemisah antara golongan yang kuat dengan yang lemah (Andri, Sumitra, 2009:404).

Zakat sudah menjadi suatu kewajiban muslim yang harus ditunaikan dan bukan merupakan hak, sehingga kita tidak dapat memilih untuk membayar atau tidak. Zakat memiliki aturan yang jelas mengenai harta apa yang harus dizakatkan, batasan harta yang dikenakan zakat, demikian juga perhitungannya, karena memiliki persyaratan dan aturan baku baik alokasi, sumber, besaran maupun waktu tertentu yang telah ditetapkan oleh syariah (Wasilah \& Nurhayati Sri, 2011:278).

\section{Corporate Social Responsibility (CSR)}

Defenisi Corporate Social Responsibility (CSR) menurut World Bank dalam Public Policy for Corporate Social Responsibility tahun 2003 adalah "the commitment of business to contribute to sustainable economic development, working with employes, their families, the local community and society at large to improve quality of life, inways that are both good for business and good for development".

Berdasarkan defenisi World Bank diatas, CSR diartikan sebagai komitmen bisnis untuk berkontribusi terhadap pembangunan ekonomi yang berkelanjutan, bekerja sama dengan pekerja, keluarga mereka, komunitas lokal dan masyarakat secara luas untuk meningkatkan kualitas hidup, dengan cara-cara yang baik untuk bisnis dan juga baik untuk pembangunan. Menurut World Business Council for Sustainable Development (WBCSD) dalam id.wikipedia.org, "CSR merupakan suatu komitmen berkelanjutan oleh dunia usaha untuk bertindak etis dan memberikan kontribusi kepada pengembangan ekonomi dari http://jurnal.iain-padangsidimpuan.ac.id/index.php/JISFIM 
komunitas setempat ataupun masyarakat luas, bersamaan dengan peningkatan taraf hidup pekerjanya beserta keluarganya”(Budi Gautama Siregar, 2018:100).

Menurut Edi Suhartono, Corporate Social Responsibility (CSR) adalah suatu kepedulian organisasi bisnis untuk bertindak dengan cara-cara mereka sendiri dalam melayani kepentingan organisasi dari kepentingan punlik eksternal. Perusahaan mengintegrasikan kepedulian sosial dalam operasi bisnis mereka dan dalam interaksi mereka dengan pemangku kepentingan berdasarkan prinsip sukarela dan kemitraan (Hamdani, 2016:174).

CSR dalam persfektif Islam merupakan konsekuensi inhern dari ajaran Islam itu sendiri. Tujuan dari syariat Islam (Maqhasid al syariah) adalah maslahah sehingga bisnis adalah upaya untuk menciptakan maslahah, bukan sekedar mencari keuntungan. Kebijakan perusahaan dalam mengemban tanggung jawab sosial (CSR) terdapat tiga bentuk implementasi yang dominan, yaitu ; Tanggung jawab sosial (CSR) terhadap pelaku dalam perusahaan; Tanggung jawab sosial (CSR) terhadap lingkungan alam; Tanggung jawab sosial (CSR) terhadap kesejahteraan sosial secara umum (Budi Gautama Siregar, 2015:148).

Aktivitas-aktivitas sosial dari bank syariah merupakan nilai tambah (add value) yang dapat berimplikasi pada meningkatnya profitabilitas jangka panjang dan goodwill yang diperoleh dari citra positif dari bisnis yang dijalankan serta meningkatnya kepercayaan stakehilder terhadap kinerja bank syariah. Jika CSR tidak dilaksanakan maka akan terdapat lebih banyak biaya yang harus ditanggung perusahaan.

Sebaliknya jika melaksanakan CSR dengan baik dan aktif bekerja keras mengimbangi hak-hak dari semua stakeholders berdasarkan kewajaran, martabat, keadilan dan memastikan distribusi kekayaan yang adil dan akan memberi manfaat dalam jangka panjang terutama bagi perusahaan, masyarakat dan pemerintah (Hamdani, 2016:174).

\section{Analisis Statistik Deskriptif}

\section{Tabel 2}

Hasil Uji Statistik Deskriptif

\begin{tabular}{lccc}
\hline Keterangan & ROA & ZKT & CSR \\
\hline Mean & 2,087593 & $4,99 \mathrm{E}+08$ & $4,47 \mathrm{E}+09$ \\
Median & 1,145000 & 11974113 & $1,06 \mathrm{E}+09$ \\
Maximum & 20,13000 & $7,33 \mathrm{E}+09$ & $2,42 \mathrm{E}+10$
\end{tabular}

JISFIM: Journal of Islamic Social Finance Management, Volume 2, No 2 Tahun 2021 http://jurnal.iain-padangsidimpuan.ac.id/index.php/JISFIM 


\begin{tabular}{lccc} 
Minimum & 0,020000 & $95275 \cdot 00$ & 5000000. \\
Std. Dev. & 3,274267 & $1,29 \mathrm{E}+09$ & $6,22 \mathrm{E}+09$ \\
Skewness & 3,779067 & 3,586217 & 1,638499 \\
Kurtosis & 19,31486 & 17,03960 & 4,739833 \\
& & & \\
Sum & 112,7300 & $2,69 \mathrm{E}+10$ & $2,41 \mathrm{E}+11$ \\
Sum Sq. Dev. & 568,2036 & $8,87 \mathrm{E}+19$ & $2,05 \mathrm{E}+21$ \\
& & & \\
Observations & 54 & 54 & 54 \\
\hline Sumber: data diolah Eviews 9 & &
\end{tabular}

Berdasarkan tabel diatas dapat dilihat bahwa variabel ROA, jumlah data (N) adalah 54, dengan rata-rata ROA yaitu sebesar 2,08\%, minimumnya sebesar 0,02\%, maksimumnya sebesar 20,13\% dan standar deviasi sebesar 3,27\%. Untuk variabel ZKT, jumlah data (N) adalah 54, dengan rata-rata ZKT yaitu sebesar Rp. 4.99 juta, minimumnya sebesar Rp. 95.275, maksimumnya sebesar Rp. 7.33 juta dan standar deviasi sebesar Rp. 1.29 juta. Untuk variabel CSR, jumlah data (N) adalah 54, dengan rata-rata CSR yaitu sebesar Rp. 4.47 juta, minimumnya sebesar Rp. 500 ribu, maksimumnya sebesar Rp. 2.42 juta dan standar deviasi sebesar Rp 6.62 juta.

\section{Pemilihan Model Estimasi Data Panel}

Tabel 3

\section{Uji Hausman Test}

Correlated Random Effects - Hausman Test

Equation: Untitled

Test cross-section random effects

\begin{tabular}{lccc}
\hline Test Summary & $\begin{array}{c}\text { Chi-Sq. } \\
\text { Statistic }\end{array}$ & Chi-Sq. d.f. & Prob. \\
\hline Cross-section random & 10,479092 & 2 & 0,0053 \\
\hline
\end{tabular}

Sumber: data diolah Eviews 9

Pada tabel di atas dapat dilihat bahwa nilai prob.Cross-Section random sebesar 0,0053 yang nilainya < 0,05 sehingga dapat disimpulkan bahwa model FE lebih baik dari pada RE dan CE. Dengan demikian dalam hal ini model yang digunakan merupakan Model Efek Tetap (Fixed Effect Model). 


\section{Uji Normalitas}

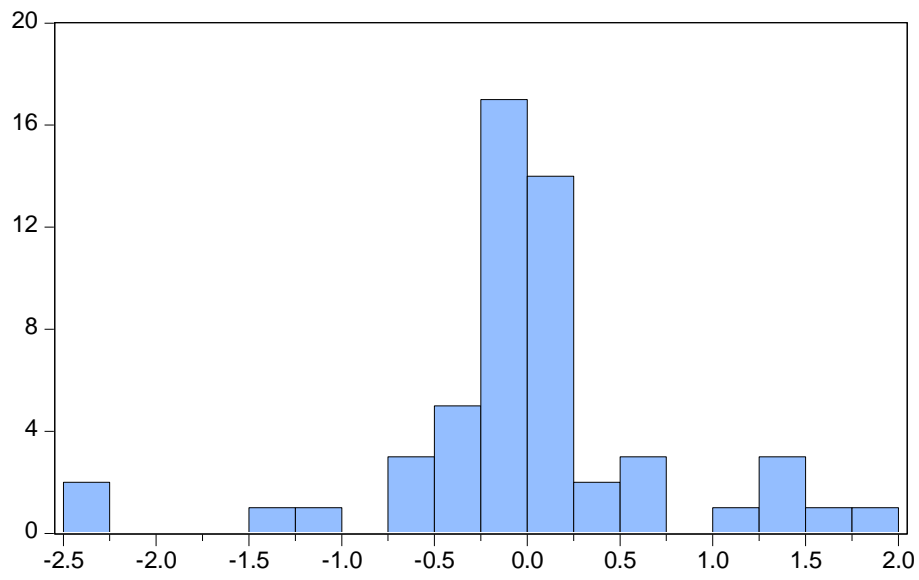

Series: Standardized Residuals

Sample 20132018

Observations 54

Mean $\quad-6.58 \mathrm{e}-17$

Median $\quad-0.022403$

Maximum $\quad 1.910296$

Minimum $\quad-2.339810$

Std. Dev. $\quad 0.753078$

Skewness $\quad-0.383447$

Kurtosis $\quad 5.607838$

Jarque-Bera $\quad 16.62512$

Probability $\quad 0.000245$

Sumber: data diolah Eviews 9

Gambar 1. Hasil Uji Normalitas

Berdasarkan hasil penelitian diatas terlihat bahwa nilai Jarque-Bera sebesar 16,62512 sementara nilai chi square dengan melihat jumlah variabel independen yang peneliti gunakan dalam penelitian ini adalah dua variabel independen dan nilai signifikan peneliti gunakan dalam hal ini sebesar 0,05 atau 5\% sehingga chi square didapat sebesar 72,15 yang berarti nilai Jarque-Bera < chi square $(16,62512<72,15)$. Sehingga dapat disimpulkan bahwa data dalam penelitian ini berdistribusi normal.

\section{Analisis Regresi Linier Berganda}

\section{Tabel 4}

\section{Analisis Regresi Linear Berganda}

Dependent Variable: LOGROA

Method: Panel Least Squares

Date: 09/24/20 Time: 07:02

Sample: 20132018

Periods included: 6

Cross-sections included: 9

Total panel (balanced) observations: 54

\begin{tabular}{c|r|r|r|r}
\hline Variable & Coefficient & Std. Error & t-Statistic & \multicolumn{1}{c}{ Prob. } \\
\hline C & $-5,301905$ & 3,298505 & $-1,607366$ & 0,1153 \\
\hline LOGZKT & 0,432333 & 0,148265 & 2,915948 & 0,0056 \\
\hline LOGCSR & $-0,085527$ & 0,126301 & $-0,677166$ & 0,5019 \\
\hline
\end{tabular}

Sumber: data diolah Eviews 9 
Adapun persamaan regresi linier berganda yang digunakan dalam penelitian ini adalah sebagai berikut:

$\mathrm{ROA}=-5,301905+0,432333 \mathrm{ZKT}-0,085527 \mathrm{CSR}$

Persamaan di atas dapat diartikan sebagai berikut; Konstanta sebesar 5,301905 artinya apabila variabel ZKT CSR dianggap konstan atau o maka nilai ROA sebesar 5,301905; Nilai koefisien ZKT sebesar 0,432333 dengan nilai positif. Hal ini berarti bahwa setiap peningkatan 1 satuan ZKT maka ROA meningkat sebesar 0,432333 satuan dengan asumsi variabel lain konstan.

\section{Uji Parsial (Uji t)}

Uji statistik t digunakan untuk menguji pengaruh masing-masing variabel independen yang digunakan terhadap variabel dependen dengan menganggap variabel lain bernilai konstan. Adapun kriteria pengujian yang digunakan sebagai berikut:

Jika $t_{\text {hitung }}<\mathrm{t}_{\text {tabel }}$ atau nilai signifikansi $>0,05$ maka $\mathrm{H}_{\mathrm{o}}$ diterima dan Ha ditolak.

Jika $t_{\text {hitung }}>\mathrm{t}_{\text {tabel }}$ atau nilai signifikansi $<0,05$ maka $\mathrm{H}_{\mathrm{o}}$ ditolak dan Ha diterima

\section{Tabel 5}

Hasil Uji t

\begin{tabular}{crrrr}
\hline Variable & Coefficient & Std. Error & t-Statistic & Prob. \\
\hline C & $-5,301905$ & 3,298505 & $-1,607366$ & 0,1153 \\
LOGZKT & 0,432333 & 0,148265 & 2,915948 & 0,0056 \\
LOGCSR & $-0,085527$ & 0,126301 & $-0,677166$ & 0,5019
\end{tabular}

Sumber: data diolah Eviews 9

Berdasarkan hasil uji t diatas, dapat diketahui bahwa nilai $t_{\text {hitung variabel ROA sebesar }}$

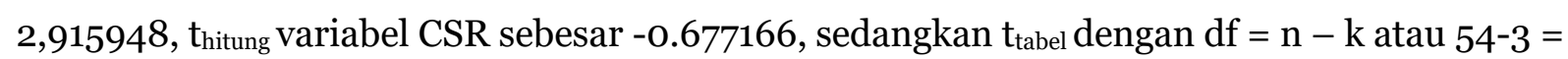
51 sehingga diperoleh $t_{\text {tabel }}=1,67528$.

\section{Uji Statistik F (Uji f)}

Uji statistik $\mathrm{F}$ digunakan untuk menguji pengaruh variabel independen secara bersama-sama atau simultan terhadap variabel dependen yang digunakan. Adapun kriteria pengujian yang digunakan sebagai berikut:

Jika F Hitung < F tabel atau nilai signifikansi > 0,05 maka $\mathrm{H}_{\mathrm{o}}$ diterima dan Ha ditolak. Jika F Hitung $>\mathrm{F}$ tabel atau nilai signifikansi $<0,05$ maka $\mathrm{H}_{\mathrm{o}}$ ditolak dan Ha diterima. 


\section{Tabel 6}

\section{Hasil Uji Statistik F (Uji F)}

Dependent Variable: LOGROA

Method: Panel Least Squares

Date: 09/24/20 Time: 07:02

Sample: 20132018

Periods included: 6

Cross-sections included: 9

Total panel (balanced) observations: 54

\begin{tabular}{cccc} 
F-statistic $\quad 10,14220$ & Durbin-Watson stat & 1,753275 \\
\hline Sumber: data diolah Eviews 9 &
\end{tabular}

Berdasarkan hasil uji $\mathrm{F}$ di atas dapat diketahui bahwa $\mathrm{F}_{\text {hitung }}$ dari kedua variabel adalah sebesar 10,14220 sedangkan $F_{\text {tabel }}$ dengan $\operatorname{df}(\mathrm{N} 1)=\mathrm{k}-1$ atau 3-1 = 2 dan $\mathrm{df}(\mathrm{N} 2)=\mathrm{N}-\mathrm{k}$ atau 54 $-3=51$ sehingga diperoleh $F_{\text {tabel }}$ sebesar 3,18 maka dapat disimpulkan bahwa $F_{\text {hitung }}>F_{\text {tabel }}$ $(10,14220>3,18)$ yang berarti bahwa kedua variabel secara simultan mempengaruhi variabel ROA pada Bank Umum Syariah di Indonesia.

\section{Uji Koefisien Determinasi $\left(R^{2}\right)$}

Uji koefisien determinasi (Adj $\mathrm{R}^{2}$ ) pada intinya mengukur seberapa jauh kemampuan model dalam menerangkan variasi variabel dependen. Nilai koefisien determinasi dapat diukur oleh nilai $\mathrm{R}^{2}$ atau Adjusted $\mathrm{R}^{2}$.

\section{Tabel 7}

\section{Uji Koefisien Determinasi}

Dependent Variable: LOGROA

Method: Panel Least Squares

Date: 09/24/20 Time: 07:02

Sample: 20132018

Periods included: 6

Cross-sections included: 9

Total panel (balanced) observations: 54

Adjusted R-squared $\quad$ o,633020 S.D. dependent var $\quad 1,380138$

Sumber: data diolah Eviews 9

Berdasarkan hasil uji diatas dapat diketahui bahwa nilai Adj $\mathrm{R}^{2}$ sebesar o,633020 atau 63\% hal ini menunjukkan bahwa variabel ZKT dan CSR berpengaruh secara simultan terhadap ROA pada Bank Umum Syariah di Indonesia. Sedangkan 37\% dipengaruhi oleh variabel lain yang tidak dibahas dalam penelitian ini.

JISFIM: Journal of Islamic Social Finance Management, Volume 2, No 2 Tahun 2021 http://jurnal.iain-padangsidimpuan.ac.id/index.php/JISFIM 


\section{Pembahasan Hasil Penelitian}

Hasil analisis diketahui bahwa secara parsial, zakat perbankan memiliki nilai thitung $>$ $t_{\text {tabel }}(2,915948>1,67528)$, maka dapat disimpulkan zakat perbankan secara parsial berpengaruh signifikan terhadap return on asset bank umum syariah di indonesia 2013-2018. Corporate social responsibility memiliki nilai $t_{\text {hitung }}<t_{\text {tabel }}(-0,677166<1,67528)$ maka dapat disimpulkan corporate social responsibility secara parsial tidak berpengaruh signifikan terhadap return on asset Bank Umum Syariah di Indonesia 2013-2018. Secara simultan, zakat perbankan dan corporate social responsibility memiliki nilai $\mathrm{F}_{\text {hitung }}>\mathrm{F}_{\text {tabel }}(10,14220>3,18)$ maka dapat disimpulkan bahwa zakat perbankan dan corporate social responsibility secara simultan mempengaruhi zakat bank umum syariah di indonesia. Hasil koefisien determinasi $\left(\mathrm{R}^{2}\right)$ diperoleh $\mathrm{R}^{2}$ sebesar 0,633020. Hal ini menunjukkan 63,30 \% setiap pertumbuhan zakat perbankan dapat dijelaskan oleh variabel zakat perbankan dan corporate social responsibility sisanya 36,70 \% diterangkan oleh variabel lain yang tidak dimasukkan dalam penelitian ini.

\section{KESIMPULAN}

Berdasarkan hasil penelitian, maka peneliti mengambil kesimpulan sebagai berikut secara parsial, variabel Zakat Perbankan memiliki nilai $t_{\text {hitung }}>t_{\text {tabel }}(2,915948>1,67528)$ maka dapat disimpulkan $\mathrm{H}_{\mathrm{o}}$ ditolak $\mathrm{H}_{\mathrm{a}}$ diterima. Jadi dari uji tersebut dapat disimpulkan bahwa variabel Zakat Perbankan secara parsial berpengaruh signifikan terhadap return on asset Bank Umum Syariah di Indonesia 2013-2018. Secara parsial, variabel Corporate Social Responsibility memiliki nilai $t_{\text {hitung }}<\mathrm{t}_{\text {tabel }}(-0,677166<1,67528)$ maka dapat disimpulkan $\mathrm{H}_{\mathrm{o}}$ diterima dan $\mathrm{H}_{\mathrm{a}}$ ditolak. Jadi dari uji tersebut dapat disimpulkan bahwa variabel Corporate Social Responsibility secara parsial tidak berpengaruh signifikan terhadap return on asset Bank Umum Syariah di Indonesia 2013-2018. Secara simultan, variabel Zakat Perbankan dan Corporate Social Responsibility memiliki nilai $\mathrm{F}_{\text {hitung }}>\mathrm{F}_{\text {tabel }}(10,14220>3,18)$ yang berarti bahwa kedua variabel tersebut secara simultan mempengaruhi variabel return on asset Bank Umum Syariah di Indonesia 2013-2018. 


\section{DAFTAR PUSTAKA}

Abdillah, Ardhi. (2015). Pengaruh Penerapan Good Corporate Governance Terhadap Kinerja Keuangan. 25(2), 7.

Batubara, Damri. (2020). Pemahaman, Pelaksanaan Zakat Hasil Sawit Oleh Para Petani Di Kecamatan Angkola Sangkunur Kabupaten Tapanuli Selatan. 6(1), 17.

Bungin, Bungin. (2001). Metode Penelitian Sosial: Format-Format Kuantitatif dan Kualitatif. Airlangga University Press.

Fahmi, Irham. (2015). Analisis Laoran Keuangan. Alfabeta.

Hafidhuddin, Didin. (2002). Zakat Dalam Perekonomian Modern. Gema Insani Press.

Hafidhuddin, Didin. (2007). Agar Harta Bertambah Berkah. Gema Insani Press.

Hamdani. (2016). Good Corporate Governance. Mitra Wacana Media.

Hery. (2015). Analisis Laporan Keuangan. CAPS.

Ikapi, Anggota. (2008). Undang-Undang Perbankan Syariah dan Surat Berharga Syariah Negara. Fokus Media.

Jumingan. (2011). Analisis Laporan Keuangan. Bumi Aksara.

Kasmir. (2008). Manajemen Perbankan. Rajawali.

Kuncoro, Mudrajat. (2009). Metode Riset Untuk Bisnis dan Ekonomi. Erlangga.

Nizamullah. (n.d.). Pengaruh Penerapan Good Corporate Governance Terhadap Kinerja Keuangan (Studi Empiris Pada Perusahaan Perbankan yang Terdaftar di. Jurnal Akuntansi, 12.

Nizar, Ahmad. (2016). Metode Penelitian. CiptaPustaka Media.

Siregar, Budi Gautama. (2015). Penerapan Corporate Social Responsibility (CSR) Dalam Pandangan Islam. 14.

JISFIM: Journal of Islamic Social Finance Management, Volume 2, No 2 Tahun 2021 http://jurnal.iain-padangsidimpuan.ac.id/index.php/JISFIM 
Siregar, Budi Gautama. (2018). Analisis Pengaruh Corporate Social Responsibility (Ekonomi, Lingkungan dan Sosial) Terhadap Earning Response Coefficient Pada Perusahaan Manufaktur Dalam Issi 2012-2016. 4.

Sugiyono. (2016). Metode Penelitian Kualitatif, Kuantitatif dan $R \& D$. Alfabeta.

Sumitra, Andri. (2009). Bank dan Lembaga Keuangan Lainnya. Kencana.

Untung, Hendrik Budi. (2009). Corporate Social Responsibility. Sinar Grafika.

Wasilah, \& Sri, Nurhayati. (2011). Akuntansi Syariah di Indonesia: Edisi 2 Revisi. Salemba Empat.

Widyastuti, Cindy. (2017). Pengaruh Alokasi Dana Zakat Dan Corporate Social Responsibility Terhadap Return On Asset Pada Bank Umum Syariah Di Indonesia Periode 2012-2016. Institut Agama Islam Negeri Surakarta. http://jurnal.iain-padangsidimpuan.ac.id/index.php/JISFIM 